Jean Baudrillard: La Transparence du Mal. Essai sur les phénomènes extrêmes, Galilée, Paris, januar 1990, 98 FF

O. Vigsø

\section{Levende begravet!}

Som den sjette i rækken af Kulturstudier har Center for Kulturforskning udgivet Subjektets status - Om subjektfilosofi, metafysik og modernitet. Redaktøren hævder i sit forord, at der nu første gang på dansk udgives en samlet omfattende redegørelse for tesen om 'subjektets død' og subjektfilosofiens nutidige status. "Denne redegørelse omfatter subjektfilosofiens historie, de forskellige fors $\emptyset \mathrm{g}$, der har været gjort på at levere alternativer til subjektfilosofien samt bud på, hvordan tanken om subjekt eller individ kan forsvares".

Bogen byder på et bredt udvalg af artikler om aktuelle tænkere, der beskæftiger sig med de nærmere omstændigheder angående subjektets død: Kierkegaard, Heidegger, Derrida, Lyotard, Habermas, Foucault og Henrich.

Et af de store navne i denne forbindelse er som bekendt Manfred Frank, der her imødegår Derrida under overskriften "Til forsvar for metafysikken".

Bogen lever fint op til sin titel og præsenterer spændvidden og afstandene i en debat, hvor konsekvenserne og rækkevidden af de forskellige synspunkter ellers kun sjældent synes at foresvæve kombattanterne.

Hans Hauge (red.): Subjektets status - Om subjektfilosofi, metafysik og modernitet. Kulturstudier 6, Århus Universitetsforlag 1990, 168 sider.

H. Ørnstrup

\section{Sociologiens $\mathbf{A}-\mathbf{Z}$}

I 1931 udkom, under Alfred Vierkandts ledelse, den store Handwörterbuch der Soziologie på forlaget Enke. At man efter krigen kunne genudgive det i 1959 fortæller om dets format. Vierkandt skrev i forordet, at værket ville fastlægge "den sociologiske bevægelses nuværende stade i en kodifikationsakt". Nu ser det ud som om den tyske sociologi atter lægger an til en form for kodifikation.

167 sociologer - men ikke nogen af de rigtig store kanoner - kommer til orde i artikler, der behandler specifikke sociologiske nøglekategorier (differentiering, magt, system, byttet, og så videre), diverse specialdiscipliner (militærsociologi, socialepidemiologi, medicinsociologi, kunstsociologi, etc.) og en række felter, der grænser op til 'sociologien' (kritisk teori, kybernetik, katastrofeteori, systemteori og meget andet).

Artiklerne er formaliseret på en overskuelig måde og hvert opslag afsluttes med en i reglen fyldig bibliografi - en 
tragi-komisk undtagelse udgør østtyskeren Rudi Weidigs artikel om marxistisk sociologi. Gad vide, hvordan han har det med det bidrag i disse dage. Men genrelt er værket bundsolidt, informativt.

Kort og godt er det nu muligt - både for lægmand og den velbevandrede - at sondere det sociologiske terræn og ikke mindst hente forslag til videre læsning.

G. Endruweit/ Giesela Trommsdorff (udg.): Wörterbuch der Soziologie, Stuttgart, EnkeDTV 1989, 872 s. DM. 68.

H. Ørnstrup

\section{Le Fuchs}

Efter samtalebøger med først Georges Dumézil (1987) og siden Claude LéviStrauss (1988) har Didier Eribon, journalist ved Le Nouvel Observateur, nu kastet sig over den franske idéhistoriker Michel Foucault (1926-1984). Resultatet er blevet en flot og meget anbefalelsesværdig bog, der indeholder alt det, som hører den klassiske intellektuelle biografi til: barndommen i det kvælende provinsmiljø i Poitiers, den gamle historielærer, som indgyder den første interesse, den mere end flittige studerende, som får tilnavnet le Fuchs, opholdet i den mørke skandinaviske vinter i Uppsala, hvor Galskabens historie (1961) bliver til, medieberømmelsen efter Ordene og tingene (1966), tiltrædelsesforelæsningen på Collège de France, AIDS-sygdommen. Osv. Osv.
Men det, som først og fremmest gør indtryk ved bogen, er, at den tillige er "en kollektiv historie", der tegner konturerne af flere epoker og flere kulturelle registre. Vi får et fint indblik i miljøet omkring Ecole normale supérieure i Rue d'Ulm, som var den centrale læreanstalt i efterkrigsårene, i strukturalisme-striden i 60 'erne, i venstrefløjens transformationer efter 68, i enkeltpersoners og enkeltinstitutioners støre betydning for den franske intelligentsia: Georges Canquilhem, Vincennes-universitetet, Collège de France osv.

For dem, som $\emptyset$ nsker at $1 \emptyset$ fte dynen lidt, kan der henvises til Hervé Guiberts selvbiografiske nøgleroman $A$ un ami qui ne m'a pas sauvé la vie (Gallimard 1990), der bl. a. beskriver Foucaults homoseksualitet og sidste dage på hospitalet.

Didier Eribon: Michel Foucault. Paris: Flammarion 1989.

Hervé Guibert: $A$ un ami qui ne $m$ 'a pas sauvé la vie. Paris: Gallimard 1990.

F. Frandsen 